А. Л. ЮРГАНОВ

\title{
«ПОДПОЛЬНАЯ ТИПОГРАФИЯ» И «ВОЕННЫЙ ЗАГОВОР» КАК АРГУМЕНТЫ СТАЛИНА В БОРЬБЕ ПРОТИВ ОБЪЕДИНЕННОЙ ОППОзИциИ (1927)
}

\author{
THE "UNDERGROUND TYPOGRAPHY” AND “MILITARY \\ CONSPIRACY" AS STALIN'S ARGUMENTS AGAINST \\ THE UNITED OPPOSITION (1927)
}

The article examines the most acute phase of Stalin's confrontation with the so-called United Opposition before the $15^{\text {th }}$ Congress of the Bolshevik Party in 1927. Stalin and Trotsky created different ideological models in this confrontation. The opposition proceeded from arguments of a purely rational nature, which they believed must convince the leaders of the party to cede power. This power, had, in the opposition's opinion been usurped by "Stalin's faction." The General Secretary of the Party, using all means available to him, including mass propaganda, created plausible illusions of a "war plot" against the Party and the Soviet power, which were supposed to help eliminate unwanted critics of Stalin from the political arena. Criticism of Stalin's power in 1927 reached its climax and threatened to bring down the entire propaganda machine. Stalinism in its earliest phase of existence manifested itself as a sphere of paranoid indoctrination of the masses into something that did not exist in reality. The media said nothing about the real arguments of the United Opposition, but actively discussed the invented "facts of confrontation" between the Bolshevik Party and the opposition. The fear instilled by Stalinism was a fear with a mythology of intimidation directed at anyone who wanted to understand the situation more rationally.

Keywords: Joseph Stalin, Leon Trotsky, Grigory Zinoviev, Lev Kamenev, October plenum of the Central Committee of the CPSU (b), Stalinism, United Opposition.

Andrei L. Yurganov - D.Sc. in History, professor, Russian State University for the Humanities. E-mail: Iurganov@yandex.ru ORCID: https://orcid.org/0000-0001-5409-2578

1 Citation: A. L. YURGANov, “Podpol'naia tipografia" i "voiennyi zagovor" kak argumenty Stalina v bor'be protiv ob'edinennoi oppozitsii (1927) [The "underground typography" and "military conspiracy" as Stalin's arguments against the united opposition (1927)], RussianStudiesHu 3, no. 1 (2021): 237-273. DOI: 10.38210/RUSTUDH.2021.3.7

DOI: 10.38210/RUSTUDH.2021.3.7 
В конце ноября 1927 г. в сатирическом журнале «Крокодил» (№44), выходившем большим тиражом, была опубликована политическая карикатура под названием «Подпольная типография». На рисунке изображены вполне конкретные деятели объединенной оппозиции: К. Радек, Л. Каменев, Л. Троцкий. Лишь одна фигура может вызывать разные толкования в атрибуции - но, скорее всего, в левом углу типографии изображен Г. Сокольников.

Криминального вида паренек приносит в типографию шрифт без трех букв: В, К, П. Зрителю предлагалось лицезреть осуждаемое партией поведение людей. Смысл надписи: то, что печатает оппозиция - к партии не имеет никакого отношения. Карикатура была опубликована в конце ноября, хотя основная история с «подпольной типографией» произошла в сентябре. Почему понадобилось так долго выжидать с публикацией и к каким событиям в политической жизни страны относится карикатура? Что она собой символизирует?

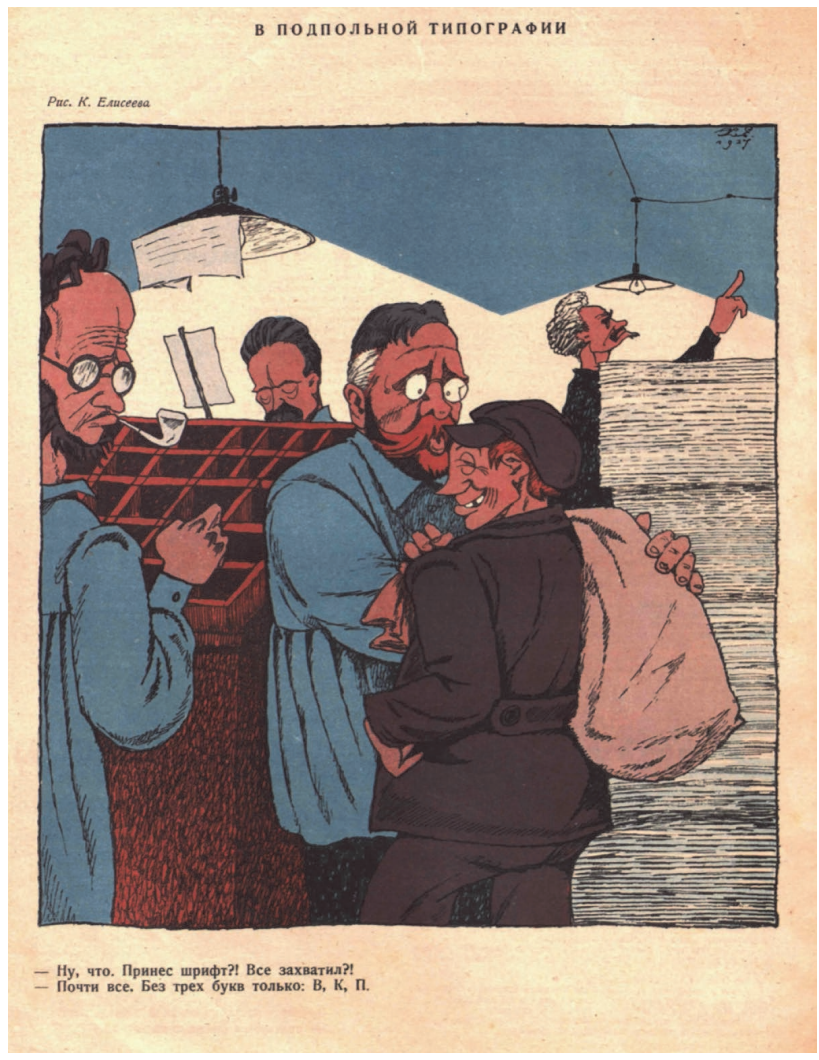


6 сентября 1927 г. Г. Зиновьев, А. Петерсон, Н. Муралов, Л. Троцкий написали письмо «В Политбюро ЦК ВКП(б), в Президиум ЦКК, в ИККИ». Как отметил Троцкий, документ был написан в значительной мере им самим. В письме было сказано, что борьба с объединенной оппозицией принимает вид политической травли - во главе ее находится Сталин, которому подчиняются все органы советской печати. Оппозиционеры как в воду глядели, а возможно знали (или догадывались) о готовящейся провокации:

«...любая пошлость, любая ложь, любая кляуза найдут место в печати, если они направлены против оппозиции»².

В августе 1927 г. Е. Преображенский написал «письмо партийному съезду» с таким названием «За что нас исключили из партии?». Речь шла об исключении из партии Преображенского, Серебрякова, Шарова, Мрачковского, Воробьева и др. «за организацию нелегальной типографии». По мнению Преображенского, не ставился вопрос - «почему эти большевики, вместе с сотнями и тысячами более молодых партийцев были вынуждены на одном из этапов нашей революции организовать нелегальное печатание своих документов, нарушать партийную дисциплину и т.д.?»3.

Оппозиция элементарно лишена права выражать свои взгляды:

«Если мне скажут: „эти требования легальны”, то я задаю вопрос, почему же в партийной печати нам не давали и не дают, за исключением аптекарской дозы в „Дискуссионном листке” раз за два года, эти требования защищать? Почему десятки статей оппозиционеров брошены в корзину партийных газет, почему запрещена для печати наша платформа, за печатание и распространение которой, за подпись под которой выброшено из партии 600 человек только за последние два месяца?»4.

Однако, как видно, никто из упомянутых выше большевиков, исключенных из партии за нелегальную деятельность, не изображен в карикатуре журнала «Крокодил». Да и само название рисунка инкриминиру-

2 Ю. ФЕЛьштинский (ред.), Архив Троцкого. Коммунистическая оппозиция в СССР. 19231927 (Москва: «Терра», 1990. Т.4), 105.

3 ФЕЛЬштинский, Архив Троцкого (Т.4), 83.

4 ФЕльштинский, Архив Троцкого (Т.4), 84. 
ет нечто более серьезное, - «подпольная типография». «Нелегальная» - значит партией неразрешенная; «подпольная» - значит противогосударственная.

«У большевиков нет подпольных типографий» - сказал Г. Л. Шкловский, старейший член РСДРП с 1898 г., участник Революции 1905-1907 гг., когда во время выступления на октябрьском пленуме ЦК и ЦКК (1927) ему был задан вопрос - «А подпольная типография?». ${ }^{5}$

В своем выступлении против объединенной оппозиции на том же октябрьском пленуме ЦК и ЦКК Н. И. Бухарин так определил границы «легальности», говоря о типографии оппозиционеров: сначала была «нарушена партийная легальность, потом была нарушена советская легальность». ${ }^{6}$

Сталин, зная, что оппозиция будет вынуждена при подготовке к XV съезду партии переходить в нелегальное состояние для печатания своих материалов, пошел по пути, который и был предсказан оппозицией...

В сентябрьском (1927) проекте платформы большевиков-ленинцев к предстоящему XV съезду ВКП(б) говорилось о том, как именно «группа Сталина» спорит с оппозицией:

«Ничто не свидетельствует в такой мере о политической неправоте группы Сталина, как ее непрестанное стремление спорить не с нашими подлинными взглядами, а с выдуманными взглядами [курсив мой - А.Ю.], которых мы никогда не разделяли и не разделяем».?

8 сентября 1927 г. состоялось заседание Политбюро и Президиума ЦКК, на котором произошла грубая перепалка оппозиции с фракцией сталинского большинства. Взаимная дискредитация дошла до апогея.

1 октября 1927 г. И. Смилга, И. Бакаев, Г. Евдокимов, Г. Зиновьев, Л. Троцкий обратились в Политбюро ЦК ВКП(б) и Президиум ЦКК с письмом о

5 А. К. СоРокИн, И. И. КУДРявцЕВ, М. И. Одинцов, А.В. Репников (ред.), Объединенный пленум ЦК и ЦКК ВКП(б) 21-23 октября 1927 г.: Документы и материалы (Москва: Политическая энциклопедия, 2018), 146.

6 СОРОКИН, КУДРяВЦЕВ, ОДИНЦОВ, РЕПнИКОВ, Объединенный пленУм ЦК И ЦКК ВКП(б) 21-23 октября 1927 г., 161.

7 ФЕЛЬштинский, Архив Троцкого (Т.4), 170. 
событии, произошедшим в ночь с 12 на 13 сентября, когда у некоторых членов партии были произведены обыски.

Ход событий излагался в письме таким образом. 15 сентября Секретариат ЦКК заслушал доклад Е. Ярославского «Об участии членов ВКП(б) в деятельности нелегальной контрреволюционной организации вместе с беспартийными» и постановил - признать действия ОГпУ правильными. 22 сентября от имени Политбюро и Президиума цКК было разослано по всем партийным организациям извещение о раскрытии «подпольной типографии». В этом извещении говорилось:

«Часть арестованных беспартийных действительно связана с некоторыми лицами из военной среды, помышляющими о военном перевороте в СССР по типу переворота Пилсудского»․

Это извещение целиком и полностью основывалось на том, что сообщало ОГпу:

«12 сентября 1927 г. ОГПУ узнало, что к одному из бывших офицеров врангелевской армии обратился некий гражданин щербаков, сын бывшего фабриканта, беспартийный, с предложением достать шапирограф; почти в то же время были получены сведения, что к тому же лицу обращался и некий Тверской, служащий, беспартийный, оказавшийся в ближайших связях с щербаковым, с сообщениями об организации военного переворота в СССР в ближайшем будущем; ОГПУ, в соответствии с означенной информацией, произвело обыск того же 12 числа ночью на квартире щербакова, причем, здесь была обнаружена нелегальная типография, печатавшая запрещенные партией антипартийные документы оппозиции. ОГПУ считало своим долгом эту литературу отобрать и, выяснив также связи щербакова-Тверского, арестовать всех замешанных в этом деле беспартийных. Ввиду особого характера дела (организация военного переворота) и необходимости совершенно специального расследования, ОГпУ вынуждено было без промедления произвести обыск и у тех партийных, которые, как это выяснилось при обыске, оказались в непосредственных связях с нелегальной организацией щербакова-Тверского. ... Ввиду того, что показания арестованных-беспартийных

8 ФЕЛЬштинский, Архив Троцкого (Т.4), 189. 
подтвердили наличие группы, ставящей своей целью организацию вышеупомянутого военного заговора, следствие по этому делу продолжается»?.

Столь серьезное обвинение, как военный заговор, нуждалось в доказательствах подлинности. В письме оппозиционеров ощущается недоумение перед всей суммой изложенных фактов, которые свидетельствовали в глазах оппозиции о том, что «перед нами два дела» - одно об оппозиционной типографии («печатне»), а другое - о военном заговоре. Что общего между ними? Эти два дела связываются фигурой какого-то «врангелевского офицера», к которому щербаков обращался по поводу шапирографа. К нему же - «врангелевскому офицеру» - обращался и некий человек по фамилии Тверской, сообщая о заговоре военных людей.

23 сентября Зиновьев, Смилга и Петерсон написали письмо к партийным организациям, в котором они поставили вопросы, вызывающие сомнение в правдивости всей этой туманной истории:

«Кто этот врангелевский офицер? Как его фамилия? Почему она умалчивается? Арестован ли он? Почему именно к этому врангелевскому офицеру как раз одновременно обращаются и за шапирографом и с сообщениями о военном перевороте в СССР „в ближайшем будущем"? С какой целью делается ему это последнее сообщение? Кто должен был делать этот военный переворот „в ближайшем будущем"? Какая группа? Организация? Лица?»0.

Политбюро ЦК ВКП(б) и Президиум ЦКК ответили, но не им лично - а всем партийным организациям - письмом Менжинского, председателя ОГПУ, обращенного в Секретариат цК ВКП(б), в котором неожиданно открылась странная правда, что «врангелевский офицер» на самом деле никакой не враг, он агент ОГПу, который помогал не раз раскрывать «белогвардейские заговоры». Обнаружение нелегальной типографии результат почти случайный, «побочный».

Оппозиция сразу же увидела плохо скрываемую ложь: в первом сообщении ОГПУ от 14 сентября речь шла о «врангелевском офицере», согласно извещению от 27 сентября этот «офицер» - уже положитель-

9 ФЕЛЬштинский, Архив Троцкого (Т.4), 189-190.

10 ФЕЛьштинский, Архив Троцкого (Т.4), 190. 
ный персонаж, агент ОГПУ. Авторы письма, написанного, как упоминалось выше, 1 октября 1927 г., спрашивали высшие партийные органы, - как соединяются между собой «оппозиционная типография» и «военный заговор», если единственное звено, их соединяющее, - агент ОГПУ? Если агент ОГПУ - по определению не контрреволюционер, то «никакого мостика от печатни к военному заговору не получается»!

«...слова о "нелегальной организации Щербакова-Тверского" могли косвенно опираться на тот факт, что оба они, хоть и по разным делам, обращались к одному и тому же врангелевскому офицеру; т. е. - белогвардейцу. Но это построение, разумеется, до основания разрушено вторым сообщением ОГПУ, свидетельствующим, что дело идет не о врангелевском офицере, а о сотруднике государственного учреждения, выполняющем секретные задачи в интересах советского государства. Следовательно, никакой нелегальной организации Щербакова-Тверского нет. Именно для того, чтобы поддержать видимость такой организации, первое сообщение ОГПУ оказалось вынуждено своего собственного агента выдать за врангелевского офицера. Таков непререкаемый язык фактов»"11.

В письме от 1 октября 1927 г. отмечалось также, что 27 и 28 сентября в органах партийного контроля рассматривались дела коммунистов, причастных к «оппозиционной печатне», однако «никто решительно не поддержал при этом обвинение коммунистов в „непосредственных связях с нелегальной организацией щербакова-Тверского"».

Более того:

«На все настояния обвиняемых, а также присутствовавших на разбирательстве в ЦКК членов ЦК Евдокимова, Зиновьева, Смилги, Троцкого ясно и точно сказать, в чем состоит нелегальная организация Щербакова-Тверского и в чем состоят связи коммунистов с этой организацией, члены МКК и ЦКК с возмущением обвиняли вопрошающих в том, что они, обвиняемые, стремятся запутать вопрос [курсив мой - А.Ю.], чтобы избежать ответа по вопросу о печатне и пр., и пр. Самое постановление МКК и ЦКК по делу о так называемой типографии обвиняет членов партии „в создании, совместно с беспартийными буржуазными интеллигентами, под-

11 ФЕльштинский, Архив Троцкого (Т.4), 192. 
польной антипартийной организации, имеющей свою нелегальную типографию”. Что МКК и ЦКК именуют оппозицию „подпольной антипартийной организацией" - это мы слышали не раз. Это вопрос особый. По вопросу об оппозиционной печатне 14 членов партии держали ответ. 12 из них исключено. Но куда же девалась связь этих коммунистов с военным заговором? Куда девалась „контрреволюционная организация щербакова-Тверского”?»12.

В письме от 1 октября были поставлены вопросы, которые предполагали только одно - оба извещения Политбюро ЦК и Президиума ЦКК партии большевиков (от 22 и 27 сентября), направленные местным парторганизациям - следует признать обманом всей партии:

«1. Когда тов. Ярославский докладывал (15 сентября) Секретариату ЦКК „об участии членов ВКП(б) в деятельности нелегальной контрреволюционной организации", знал или не знал тогда тов. Ярославский о том, что врангелевский офицер - это единственная „связь” оппозиционной печатни с военным заговором - есть агент ГПУ?

2. Если тов. Ярославский не знал этого, значит ОГпУ ввело его в заблуждение. Тогда надо установить виновных в составе ОГпу для предания их суровой каре.

3. Если тов. Ярославский знал, то почему не сообщил Секретариату, который в своем постановлении признал „действия ОГПУ правильными"? Ввел ли тов. Ярославский в заблуждение Секретариат, или же, как уже сказано, тов. Ярославский сам был введен в заблуждение ОГпу?

4. В какой момент правду о „врангелевском офицере” узнали Политбюро ЦК и Президиум ЦКК: тогда ли, когда публиковали первое извещение, или же тогда, когда получили второе извещение ОГПу, в ответ на прямой запрос тт. Зиновьева, Смилги и Петерсона?»

Значение этих вопросов ясно само собой: извещение ЦК и ЦКК обмануло партию по вопросу о мнимой связи оппозиции с военным заговором. Из этого обмана партия не вышла еще и сейчас. Наоборот, круги этого обмана все дальше расходятся по стране, приобретая все более

12 ФЕЛЬШтинский, Архив Троцкого (Т.4), 192-193. 
и более грубый характер. Кто же в этом обмане играл сознательную и активную роль? Кто оказался в нем замешан в силу фракционного ослепления, кто попустительствовал по невниманию или неряшливости, наконец, кто является действительным организатором и вдохновителем обмана? В этих вопросах необходима полная и безусловная ясность. Без внесения этой ясности немыслима и честная подготовка XV съезда партии ${ }^{13}$.

Никаких обвинений конкретным лицам, только вопросы для того, чтобы прояснить ситуацию и наказать виновных.

На этом этапе оппозиция не столько утверждала, сколько спрашивала:

«Что это за путчисты? Что это за военный заговор? На заседании Президиума ЦКК мы слышали, что этот военный заговор не имеет никакого отношения к оппозиционной печатне. Из ОГПУ мы слышали, что дело о военном заговоре продолжается. Остается надеяться, что заговор будет раскрыт и виновные понесут надлежащую кару. Но мы и на данной стадии не можем, однако, пройти мимо вопроса о военном заговоре - и не только потому, что сделана была попытка втянуть в это дело коммунистов через посредство мнимой „нелегальной организации Щербакова-Тверского", которая держалась только на одном врангелевском офицере, оказавшемся агентом ГПУ»14.

4 октября 1927 г. оппозиция изменила тон обращения в своем письме к «ЦК, ЦКК, ИККИ, ко всем членам партии», подписанном Троцким, Зиновьевым, Евдокимовым, Бакаевым, Смилгой, Петерсоном.

Стало ясно, что Секретариат цК стремится лишить оппозицию возможности встретиться на XV съезде партии с большинством депутатов, история с нелегальной типографией злонамеренно связывается с предполагаемым военным заговором. В письме от 4 октября оппозиционеры сообщали еще об одном обмане:

«...Политбюро, по предложению Сталина, запретило платформу большевиков-ленинцев (оппозиции), тогда как его прямая обязанность была напечатать платформу к сведению всей партии.

13 ФЕЛьштинский, Архив Троцкого (Т.4), 194.

14 ФЕЛьштинский, Архив Троцкого (Т.4), 195. 
Почти по всему СССР в конце октября назначены уже губернские конференции для выборов делегатов на XV съезд. Между тем, т. н. „дискуссию” обещают допустить лишь с 1 ноября - т. е. после выборов делегатов на съезд. Это ли не обман? Это ли не подделка съезда? Такой образ действий есть попрание партийного устава, неслыханный удар по съезду и по партии ${ }^{15}$.

Попытка напечатать оппозиционные материалы к съезду сорвана карательными органами государства:

«14 безупречных партийцев занялись перепечаткой платформы на машинках, на шапирографах и пр. Они подверглись обыскам со стороны ГПУ. 12 из них ЦКК исключила из партии. Исключения идут повсеместно».

Предложение оппозиции - создать комиссию по расследованию случившегося - было отклонено. Саму затею связать «заговор» с Троцким авторы письма назвали «более острым блюдом», приготовить которое Сталин и его окружение («заправилы грязного дела») пока не решаются: «очевидно, что час еще не пробил».

В письме от 4 октября уже названо имя заказчика всей этой провокации:

«Все нити ведут к Сталину. Без его согласия, одобрения, поощрения никогда бы никто не осмелился бросить в партийные ряды основанные на подлоге обвинения оппозиционных коммунистов в участии в контрреволюционной организации. То, что Сталин делает в большом масштабе, на местах делается в малом» ${ }^{16}$.

Считая своей козырной картой миф о «врангелевском офицере», Троцкий недооценил Сталина как тактика-интригана, который мог ведь и специально «подбросить» такую тему, чтобы затем нанести сильный контрудар. С первых минут октябрьского пленума ЦК и ЦКК Троцкий потребовал, чтобы в порядок обсуждения был внесен вопрос о «врангелевском офицере». Более того, все, что Троцкий успел сказать в самом начале пленума (это касалось разных вопросов, в том числе и сокры- 
тия основного документа оппозиции - ее программы) было решено в стенограмму «не помещать» ${ }^{17}$. Вопрос о типографии и ее якобы «нелегальной» - с точки зрения сталинской группировки - деятельности был для оппозиции вопросом «внутрипартийной демократии»: если не дают права сказать о своем мнении, то допустимо всякое сопротивление насилию над меньшинством.

22 октября 1927 г. (во второй день заседания пленума ЦК и ЦКК) Г. Зиновьев говорил:

«У нас в партии стараются теперь создать представление, будто самое слово „платформа" это уже нечто неслыханное в большевистской среде. А между тем это вовсе не так. Мы знаем, что платформы у нас в партии разные бывали. Мы знаем, что Бухарин выступал с неправильными платформами и в 1918 и в 1921 г. Что же тогда делал Владимир Ильич с этими платформами? Он не прятал их, он их печатал, он не загонял Бухарина в необходимость печатать на ротаторе, а печатал эти платформы на ротационной машине и переубеждал Бухарина и переубеждал рабочих, которые ему сочувствовали ${ }^{18}$. Зиновьев напомнил об исключении из партии в августе 1927 г. Серебрякова, Шарова, Преображенского, Саркиса, Наумова, Мрачковского, Вуйовича за то, что они печатали собственные материалы по «платформе», - такого «действительно никогда не было» ${ }^{19}$.

23 октября 1927 г. на утреннем заседании пленума Н. М. Янсон, секретарь ЦКК, поведал о деятельности не об одной «нелегальной» типографии а сразу о нескольких. Выстроилась история нелегальной деятельности оппозиции. «Первая ступень», - как выразился Янсон, - заключалась в том, что была организована нелегальная типография - не «подпольная» - в которой работали как партийцы, так и беспартийные «буржуазные интеллигенты». Об этом писалось в извещениях Политбюро и Президиума ЦКК. Янсон осторожно сказал, что «при работе этой ти-

17 СОРОКИн, КУДРявЦЕВ, ОДинцОВ, РЕПников, Объединенный пленум ЦК и ЦКК ВКП(б) 21-23 октября 1927 г., 25.

18 СОРОКИн, КУДРявЦЕВ, ОДинцОВ, РЕПников, Объединенный пленум ЦК и ЦКК ВКП(б) 21-23 октября 1927 г., 122.

19 СОРОКИн, КУДРявЦЕВ, ОдинцОВ, РЕПников, Объединенный пленум ЦК И ЦКК ВКП(б) 21-23 октября 1927 г., 123. 
пографии беспартийные, принимавшие там непосредственное участие, были в связи с людьми, болтавшими о военном заговоре». Иными словами, об оппозиции сказано, как о «нелегальной» деятельности в партии, о военном заговоре - как о другой теме, ибо здесь участвуют уже «беспартийные».

Янсон напомнил, что, не скрывая своего участия в типографском деле, Преображенский, Серебряков и Шаров написали заявление в Президиум ЦКК и Политбюро, в котором в «самой грубой, невежливой форме, осмеивая действия руководящих органов партии, с неслыханной спесью заявляли, что они являются организаторами и ответчиками за всю деятельность этой типографии» ${ }^{20}$. Они выступили с ходатайством об освобождении беспартийных. Но фокус состоял в том, что - то ли случайно, то ли из-за дьявольской хитрости кого-то - беспартийные «попались» на другом преступлении, как соучастники возможного «военного заговора».

Никаких решений по заявлению «трех» принято не было. Решили «отложить», чтобы «посмотреть, как будут развиваться события дальше». Если существовал план борьбы с оппозицией, то он не мог быть одноходовым.

Оппозиция нашла нового человека, способного выполнить главную задачу - отпечатать «платформу» оппозиции, чтобы с ее помощью получить большинство на XV съезде партии. Этим человеком оказался Михаил Семенович Фишелев, давний товарищ Троцкого, пребывавший с ним в эмиграции, в Америке 21 . Он был заведующим одной из типографий Мосполиграфа. Фишелев нашел еще «парочку людей» (по выражению Янсона). Отпечатана была оппозиционная «платформа» под видом произведения Дмитрия Фурманова с заголовком «Пути борьбы». Этот заголовок почти полностью совпадал с названием подлинного сборника рассказов и повестей писателя, вышедшего в 1925 году - «Путь борьбы». На обложке псевдо-Фурманова был напечатан адрес другой типографии. В последний момент, перед отправкой по всему Советскому Союзу, собирались снять обложку с «Фурмановым» и наклеить свою - оппозиционную, подлинную.

М. С. Фишелев по постановлению ЦКК был исключен из партии. Вот

20 СОРОКИН, КУДРЯВЦЕВ, ОДИНЦОВ, РЕПНИКОВ, ОбъедИненныЙ ПЛенУМ ЦК И ЦКК ВКП(б) 21-23 октября 1927 г., 131.

21 М. ФишелЕв, Om харьковской голубятни до ангарской ссылки. Москва: Политкаторжан, 1931. 
об этой ситуации, в виду обмана органов государства, сказал Янсон, «мы имеем подпольное использование советской типографии, в которой заведующим являлся бывший меньшевик»22.

История с Фишелевым произошла до 16 октября 1927 г., ибо в этот воскресный день состоялась новая типографская история. В одну из типографий Мосполиграфа пришли два человека, один из них член партии по фамилии Зильберов, заведующий вечерней сменой, а другой не из числа работников. Они приступили к набору, и уборщица, которая была тогда на дежурстве, сообщила руководству типографии, что в нерабочий день кто-то печатает неизвестно что. Когда заведующий явился в типографию, Зильберов остался на месте, а соучастник бежал. Но вскоре он был задержан. Им оказался некто по фамилии Бровер, член партии с 1917 г., бывший меньшевик, бундовец. Как утверждал Янсон, состоялся «захват советской типографии»:

«В первом случае, все-таки мы видели, что там был свой заведующий, внутренняя власть типографии как будто бы была на стороне оппозиции, а во втором случае и этого нет. Просто приходят люди с улицы, захватывают типографию и печатают»²3.

Янсон отметил то, что потом художественно выразит автор карикатуры в «Крокодиле», - воровство шрифта:

«В Ленинграде сторонники оппозиции доходят до того, что начинают воровать шрифт в типографиях. Это что означает? Это означает, что наверное в ближайшее время мы встретим издания, которые будут напечатаны в форменной подпольной типографии [курсив мой - А.Ю.] и уже не на шапирографе и не на ротаторе, а типографским способом. А затем, если такая деятельность оппозиции будет развиваться дальше, то какие мы имеем гарантии относительно того, что в один прекрасный день мы не будем слышать и не прочитаем в газетах, что где-нибудь был произведен вооруженный налет на советскую типографию... $2^{24}$.

22 СОРОКИн, КУДРявЦЕВ, ОДинцОВ, РЕПниКов, Объединенный пленум ЦК и ЦКК ВКП(б) 21-23 октября 1927 г., 132.

23 СОРОКИН, КУДРяВЦЕВ, ОДинцОВ, РЕПниКОВ, Объединенный пленУм ЦК И ЦКК ВКП(б) 21-23 октября 1927 г., 133.

24 СОРОКИН, КУДРявЦЕВ, ОДинцОВ, РЕПников, Объединенный пленум ЦК И ЦКК ВКП(б) 21-23 октября 1927 г., 133. 
Причастны ли главные руководители оппозиции к этим событиям? Янсон ответил утвердительно:

«Когда разбиралось дело первой нелегальной типографии на Президиуме ЦКК, кроме привлеченных товарищей (14 чел.), кто явился туда, на заседание? Туда явились члены Центрального Комитета тт. Троцкий, Зиновьев, Евдокимов и Смилга. Для чего они явились туда? Они явились туда для того, чтобы целиком и полностью солидаризироваться с этими подпольщиками, воодушевить их в борьбе против партии перед партийным судом и взять на себя как их юридическую защиту, так и защиту по существу. Перед этим мы имели заявление трех: Преображенского, Шарова и Серебрякова, которые заявили, что они являются организаторами этого дела техники оппозиции и отвечают за это дело. Эти три товарища близко стоят к товарищам, которые сидят здесь среди нас, возглавляя оппозицию. Какой отсюда приходиться делать вывод? Ясно, только один вывод, что все эти действия производились с полного ведома данных товарищей, и что они от них совершенно не отмежевываются, а, наоборот, солидаризируются с ними и считают эти действия правильными» ${ }^{25}$.

Именно эта причастность руководителей оппозиции к нелегальной/ подпольной типографии стала фактом для «партии» (в сталинском понимании), который свидетельствовал о недопустимости пребывания Троцкого и Зиновьева в составе Центрального Комитета. Янсон так и сказал:

«Поэтому Президиум ЦКК решил поставить перед этим Объединенным Пленумом вопрос, допустимо ли дальнейшее пребывание в числе членов ЦК тт. Зиновьева и Троцкого» ${ }^{26}$.

Кто-то крикнул: «И в числе членов партии».

Янсон продолжал: «...как главных вдохновителей этой деятельности, как главных лидеров фракции, превращающейся в новую партию... при обмене мнений весь Президиум ЦКК единодушно

25 СОРОКИН, КУДРЯВЦЕВ, ОДИНЦОВ, РЕПнИКОВ, ОбъедИненный пленУм ЦК И ЦКК ВКП(б) 21-23 октября 1927 г., 133-134. 
пришел к такому выводу, что тт. Зиновьева и Троцкого из состава ЦК необходимо исключить теперь же на этом Пленуме»²7.

Сатирическое изображение в журнале «Крокодил» лидеров объединенной оппозиции, лично работающих в «подпольной типографии» это художественный образ, воплощающий собой причину партийного решения об исключении Троцкого и Зиновьева из состава ЦК партии.

Троцкий пытался торпедировать Янсона вопросом о «врангелевском офицере», который оказался не врагом, а сотрудником ОГПУ. Ему казалось, что сталинский аппарат промахнулся, и теперь стоит возбудить внимание к этой позорной «клевете» (по выражению Троцкого). Но интрига была продумана заранее, и Троцкий недооценил врага. Янсон, судя по всему, был в курсе интриги:

«Вы, т. Троцкий, получите еще сегодня же [здесь и далее курсив мой - А.Ю.] свою долю по поводу заговора, сегодня получите то, что вам надлежит получить, если вы не угомонитесь и будете иметь желание здесь говорить по поводу заговора»²8.

Весь сценарий борьбы с оппозицией был расписан по нотам. Янсон в ответ на выкрики «из партии надо гнать» сообщил, что решение фактически уже принято, но оно другое:

«...этого [исключения из состава ЦК - А.Ю.] на данной стадии достаточно. Затем на XV съезде партии мы предъявим оппозиции полный счет, и я надеюсь, что XV съезд партии скажет им: одно из двух - или преклоните голову перед партией, перед ее волей, или уходите из партии!»².

Когда температура кипения страстей дошла до предела, на трибуну поднялся тот, на кого делал ставку Сталин. Это был В. Р. Менжинский, руководитель ОГПУ. Он подробнейшим образом рассказал о том, как

27 СОРОКИн, КУДРявЦЕВ, ОДинцОВ, РЕПниКов, Объединенный пленум ЦК и ЦКК ВКП(б) 21-23 октября 1927 г., 134.

28 СОРОКИН, КУДРЯВЦЕВ, ОДИНЦОВ, РЕПниКОВ, Объединенный пленУм ЦК и ЦКК ВКП(б) 21-23 октября 1927 г., 135.

29 СОРОКИН, КУДРяВЦЕВ, ОДинцОВ, РЕПников, Объединенный пленум ЦК И ЦКК ВКП(б) 21-23 октября 1927 г., 135. 
расследуется дело о возможном военном заговоре. Суть сталинской интриги заключалась не в том, чтобы напрямую связать деятельность «нелегальной» типографии с военным заговором, как думал Троцкий. Задумка Сталина оказалась хитрее! Смысл всего этого хаоса антисоветских разговоров в пользу военного переворота «по типу Пилсудского» сводился не к тому, что заговор состоялся, имеются заговорщики, исполнители. Нет, конечно! Показано пробудившееся антисоветское подполье, которое ненавидит не только тех, кто у власти, но и тех, кто против Сталина - объединенную оппозицию, называя ее руководителей «трусливыми евреями».

«Менжинский сообщил, что 13 сентября 1927 г. состоялся допрос Тверского, лектора бюро мгСпС и репортера "Рабочей газеты". Ему "под большим секретом" Нина Владимировна Иванова, преподаватель русского языка и литературы, поведала о том, что ей рассказал муж - по фамилии Большаков».

Большаков ей говорил о том, что в военных кругах существует движение, во главе которого стоят тт. Троцкий и Каменев (С.С.), очевидно, военный. Что это организация активная. О том, что организация предполагает совершить переворот - не говорилось, но это само собой подразумевалось по разговору с Ивановой. ${ }^{30}$

На этом зыбком основании - беседы с гражданкой Ивановой - Тверской заключил, что ее муж, Большаков, состоит членом какой-то тайной организации.

В дальнейшем этот загадочный Тверской (Менжинский не упомянул его имени и отчества) сказал, что знаком с Трифоном Щербаковым, который работал в типографии. У этого Трифона имеется родной брат Николай, военный.

Из допроса Нины Владимировны Ивановой (15 сентября 1927 г.) следует, что «в конце июля на даче в с. Братовщина по Ярославской ж. д. вечером в разговоре мой муж Большаков, Дмитрий Гаврилович, рассказал мне, что существует в военных кругах организация, возглавляемая военным Каменевым (С.С.), которая предполагает совершить переворот. Организация представляет собой нечто среднее между оппозицией и не оппозицией, и сам Большаков входит в нее в качестве члена. Сна-

30 СОРОКИн, КУДРЯВЦЕВ, ОДинЦОВ, РЕПниКОВ, Объединенный пленУм ЦК И ЦКК ВКП(б) 21-23 октября 1927 г., 149. 
чала меня это поразило, но потом не поверила ему, так как он обычно немного рисуется [курсив мой - А.Ю.]» ${ }^{31}$.

Сам Большаков на допросе 15 сентября 1927 г. сказал:

«В конце мая или в начале июня я встретился с одним военным, приехавшим из Маньчжурии, фамилии его я не помню. Меня с ним познакомил Шеко Кузьма Васильевич, кандидат ВКП(б), работает в Мосстрое на заготовке, адрес его не помню. Этот военный в одном из разговоров сказал мне, что в военных кругах наблюдается сочувственное отношение к перевороту, совершенному Пилсудским в Польше, так как он прошел почти безболезненно и бесшумно, без всякой интервенции и войны. Я выразил удивление, почему захват власти военной организацией в Польше вызывает сочувствие в военных кругах, он ответил мне, что среди военных партийцев в СССР есть сильное течение в пользу такого же переворота и в СССР. Кто стоит во главе этого течения, он не говорил, сказал только, что если бы Троцкий был не еврей, а следовательно, не трус, то он стал бы во главе такого переворота. От всего разговора с этим военным у меня осталось впечатление, что со-

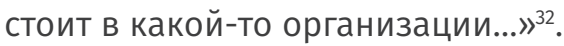

Разговоры, разговоры, разговоры, ни к чему никого не обязывающие - то ли сочиненные, то ли реальные. Но суть не в том. Никто и не собирался сочинять байку про Троцкого - организатора военного переворота, план был другой. Когда Менжинский закончил наконец свой длинный пересказ всех этих бесед о военном заговоре, Троцкий воскликнул: «Сталин создает амальгаму, Бухарин пишет „теоретические” статьи».

Сплав ртути с другим металлом (или амальгама) - это характеристика сталинского режима, в котором один создает интриги - это Сталин, а Бухарин пишет теоретические труды.

Следующим и было выступление Бухарина. Оно раскрыло план Сталина по борьбе с оппозицией. Оказалось, что вся эта история разговоров о

31 СОРОКИН, КУДРяВЦЕВ, ОДинцОВ, РЕПников, Объединенный пленУм ЦК И ЦКК ВКП(б) 21-23 октября 1927 г., 149.

32 СОРОКИн, КУДРяВЦЕВ, ОДинцОВ, РЕПников, Объединенный пленум ЦК и ЦКК ВКП(б) 21-23 октября 1927 г., 150. 
готовящемся военном заговоре была нужна не для того, чтобы напрямую связать Троцкого с заговорщиками - никто, конечно, не поверил бы в это - а для того, чтобы сказать, что борьба Троцкого против «партии» (или «большинства») развязывает руки «третьей силе». Бухарин так и сказал:

«Ленин неоднократно утверждал, в особенности в момент острых партийных потрясений, что в случае крупных разногласий внутри партии и в том случае, если одна из частей партии выступает за рамки, дозволенные партийным уставом, и начинает трясти организационные принципы [здесь и далее курсив мой - А.Ю.] партии, то такое положение использует третья сила, т.е. те социально-классовые группировки, которые ни прямо, ни косвенно ничего общего с нашей партией не имеют. Эти социально-классовые группировки ползут в ту щель, которая образуется внутри партии, усиливают давление на стенки этой щели и, таким образом, вклиниваясь все больше и больше в наши внутрипартийные разногласия, используя обострение и углубление внутрипартийных разногласий, могут привести к потрясению всей системы пролетарской диктатуры».

Разговоры как разговоры (никто пока не знает - что за ними), а тень брошена: оппозиция не виновата в самом военном заговоре (так пока считается), но борьба с «партией» (сталинским большинством) порождает третью силу, враждебную уже не только партии, но всему советскому государству. Вот тут нечем крыть! Чего опасался сталинский лагерь, больше всего? Если верить словам Бухарина, то страх они испытывали перед призраком «второй партии»: нет и не может быть тогда никакой «диктатуры пролетариата»! Не может быть двух советских армий, двух ГПУ. Бухарин устрашал тем, что в стране оживают фашистские настроения «по линии антисемитизма», «нэповские элементы».

«...методами нарушения внутрипартийной дисциплины и методами образования второй партии вы вынуждены были связаться с буржуазными интеллигентами. Факт или не факт, что такая связь создалась? Это есть факт. Персона, символизирующая такой факт, есть Щербаков. Факт или не факт, что там этими элементами ве-

33 СОРОКИн, КУДРяВЦЕВ, ОдинцОВ, РЕПников, Объединенный пленум ЦК и ЦКК ВКП(б) 21-23 октября 1927 2., 157-158. 
лись речи с военными элементами, помышляющими о военном перевороте?». ${ }^{34}$

Его перебивали голоса из оппозиции - «Вы голосовали за исключение Преображенского?», «Тюремное заключение Фишелева?» Не так просто соединить «нэповские элементы» с Преображенским, а «фашистские настроения» с Фишелевым. Если исходить из тех опасений Бухарина, которые он высказал в своей речи - что фракция оппозиции стремительно превращается в партию, что она соединяется с «буржуазной интеллигенцией» и т. д. - то все материалы допросов подозреваемых в военном заговоре становятся более понятными (как сценарий): нужно было найти «буржуазных интеллигентов» - и их нашли, в том числе беспартийных, нужно было найти фашистов-антисемитов из числа военных («третью силу») - и их нашли тоже. Сценарий «военного заговора» в материалах Менжинского просто идеально совпадал с политическими установками Бухарина. Расчет был на то, что у оппозиции нет времени на тщательное расследование сомнительных мест в выступлении Менжинского. Нужно «утопить» оппозицию в явленном на пленуме цК и цКК обличительном потоке материалов следствия, и не дать ей времени подумать.

Бухарин хитро связал оппозицию с «военным заговором». Раз оппозиция расшатывает единство партии, то естественным образом растет и опасность со стороны «третьей силы». Формула негативного действия «внутрипартийной щели» такая: максимально усиливается угроза советской власти «там, где та или другая оппозиционная группировка переходит уже не только рамки партийной легальности, но и рамки легальности советской». Он повторил свою мысль:

«Сначала была нарушена партийная легальность, потом была нарушена советская легальность. Вы катитесь со ступеньки на ступеньку к тому, чтобы скептически относиться к тем, критиковать, ругать и проч. тех, кто помогает выловить этих субъектов, враждебных Советской власти. Через агента ГПУ нашли человека, который работал в вашей типографии и в то же время был связан с белыми. Слава ГПУ за то, что оно это сделало!»5.

34 СОРОКИн, КУДРЯВЦЕВ, ОДинцОВ, РЕПников, Объединенный пленум ЦК и ЦКК ВКП(б) 21-23 октября 1927 г., 161.

35 СОРОКИн, КУДРявЦЕВ, ОДинцОВ, РЕПников, Объединенный пленум ЦК и ЦКК ВКП(б) 21-23 октября 1927 г., 163. 
Бухарин сказал, что он отличает оппозиционное выступление в партии от выступления против советской власти. Зиновьев ему крикнул с места: «Во ВЦиК вы голосовали с левыми эсерами против Ленина (против Брестского мира)». На что Бухарин ответил:

«Верно. Так какой вывод ты делаешь из этого? Если я голосовал и нарушал тем самым партийную дисциплину (хотя это не было нарушением советской дисциплины), - разве я говорю, что это очень хорошо?» ${ }^{36}$.

В новых условиях Бухарин дал определение тому, что есть «советская легальность». Он сказал:

«Советская легальность есть не что иное, как юридическое выражение пролетарской диктатуры» $^{37}$ И продолжил: «А что значит сломать рамки пролетарской диктатуры? Это есть не что иное, как переход на рельсы буржуазной демократии»з3.

Выступавший после Бухарина М.Ф. Шкирятов выразил мнение партийного большинства о том, как диктатура класса соединяется с волей Сталина:

«Оппозиция травит т. Сталина, выливают всякую грязь, которая к нему не пристает. Не клевещите на того, который выше вас стоит. (Аплодисменты). Когда они травят, когда бьютт. Сталина, то бьют по всей системе Центрального Комитета. Тов. Сталин отра-жает волю партии, он ее проводит и наше Политбюро. (Аплодисменты) ${ }^{39}$ ».

Как видно, личность генерального секретаря ЦК ВКП(б) становится уже «отражением» воли всей большевистской партии.

36 СОРОКИн, КУДРяВЦЕВ, ОДинцОВ, РЕПниКов, Объединенный пленУм ЦК и ЦКК ВКП(б) 21-23 октября 1927 г., 161.

37 СОРОКИН, КУДРяВЦЕВ, ОДИНЦОВ, РЕПниКОВ, Объединенный пленУм ЦК И ЦКК ВКП(б) 21-23 октября 1927 г., 162.

38 СОРОКИН, КУДРЯВЦЕВ, ОДинцОВ, РЕПниКОВ, Объединенный пленУм ЦК И ЦКК ВКП(б) 21-23 октября 1927 г., 162.

39 СОРОКИН, КУДРяВЦЕВ, ОДИНЦОВ, РЕПнИКОВ, Объединенный пленум ЦК И ЦКК ВКП(б) 21-23 октября 1927 г., 167. 
Вечером, 23 октября 1927 г. первым выступил Б.А. Ройзенман. Он стал говорить о сопротивлении оппозиции действиям партии против «нелегальной» типографии. Он подчеркивал, что Г. Зиновьев, выступая на Президиуме ЦКК по поводу исключения из партии четырнадцати оппозиционеров, говорил, что «каждый член партии, каждый истинный большевик должен именно поступать так, как исключенные, т.е. должен для того, чтобы сообщить партии взгляды оппозиции, делать все вплоть до организации нелегальной типографии, пользуясь услугами даже беспартийных» ${ }^{40}$.

Ройзенман коснулся также мотива «воровства», когда речь зашла о Фишелеве, «который для нелегальной типографии ворует советский шрифт и бумагу для того, чтобы печатать антипартийный документ...»¹.

Вопрос о «нелегальной типографии» в сознании большинства на Пленуме был напрямую связан с перспективой создания «второй партии ${ }^{42}$. Ройзенман повторил, вслед за Бухариным, что оппозиция объективно способствует контрреволюции. Он знал, что уже принято решение об исключении Троцкого и Зиновьева из цК партии:

«Тов. Зиновьев, я уже вам сказал и еще раз заявляю здесь на Пленуме: конечно, никто не думает и не верит, что вы участвуете в военном заговоре и т.д., но объективно вы совершаете контрреволюцию, а что день грядущий вам сулит [курсив мой - А.Ю.], это зависит от того, как вы себя дальше поведете» ${ }^{43}$.

Голос из зала: «Зависит от вас».

Зиновьев - громко: «От Сталина» ${ }^{4}$.

Условие «прощения» Зиновьева в речи Ройзенмана озвучено так:

«Я вам скажу, т. Зиновьев, если вы действительно хотите единства партии, пусть у вас хватит мужества выйти на трибуну и заявить о

40 СОРОКИн, КУДРЯВЦЕВ, ОДинцОВ, РЕПников, Объединенный пленУм ЦК и ЦКК ВКП(б) 21-23 октября 1927 г., 171.

41 СОРОКИн, КУДРявЦЕВ, ОДинцОВ, РЕпников, Объединенный пленум ЦК и ЦКК ВКП(б) 21-23 октября 1927 г., 171.

42 СОРОКИН, КУДРЯВЦЕВ, ОДинЦОВ, РЕПниКОВ, Объединенный пленум ЦК И ЦКК ВКП(б) 21-23 октября 1927 г., 172.

43 СОРОКИн, КУДРЯВЦЕВ, ОДинцОВ, РЕПников, Объединенный пленум ЦК и ЦКК ВКП(б) 21-23 октября 1927 г., 172.

44 СОРОКИН, КУДРЯВЦЕВ, ОДинцОВ, РЕПников, Объединенный пленум ЦК и ЦКК ВКП(б) 21-23 октября 1927 г., 172. 
том, что вы отказываетесь от всякой фракционной борьбы, от антипартийных методов, от печатания в нелегальных типографиях и т.д., что в дальнейшем будете подчиняться партии» ${ }^{45}$.

Когда было дано слово Зиновьеву, он сразу начал с разоблачения сталинской игры. Оппозиция ждала ответа на вопрос, - кто такой «врангелевский офицер», и какое отношение он имеет к оппозиции, но, когда Менжинский выступил, стало ясно, какую западню придумал Сталин.

Зиновьев говорил:

«Мы просили вас в начале Пленума поставить специальным пунктом вопрос о так называемом «врангелевском офицере». Вы отказали нам в этом при бурных сценах в этом зале. Было бы естественно, - раз в партии этот вопрос вызвал большой интерес и большое возмущение, было бы естественнее, если бы вы поставили отдельно доклад председателя ОГпу по этому вопросу... Что же вы сделали вместо этого? Вы подождали, пока был поставлен вопрос об исключении двух членов ЦК, и в качестве "интермеццо" к этому вопросу, в качестве "вставки", выступил m. Менжинский [курсив мой - А.Ю.], который зачитал вам то, что вы здесь слышали. Я спрашиваю, товарищи, можно ли, защищая правое дело, прибегать к таким приемам? Не говорит ли этот прием о том, что люди, прибегающие к нему, защищают глубоко неправое дело? Что доказал этот доклад? Он доказал, что никакого заговора нет» ${ }^{46}$.

На эти слова отреагировали многие.

А. А. Сольц, перебивая Зиновьева, произнес: «Вы в тюрьме сидели бы, если бы это было так».

Острота конфликта проявила себя особенно, когда Зиновьев упомянул среди «нелегальных» документов, которые фиксировались протоколами допросов оппозиционеров, «завещание» Ленина. Его, судя по всему, тоже пытались напечатать в «нелегальной» типографии.

Зиновьев говорил:

45 СОРОКИН, КУДРяВЦЕВ, ОДИНЦОВ, РЕПниКОВ, ОбъедИненный пленУм ЦК И ЦКК ВКП(б) 21-23 октября 1927 г., 172-173.

46 СОРОКИН, КУДРяВЦЕВ, ОДИНЦОВ, РЕПниКОВ, Объединенный пленУм ЦК И ЦКК ВКП(б) 21-23 октября 1927 г., 174. 
«Сталин вынужден угощать вас все более и более острыми блюдами, которые никак не лезут в рот партии. (Шум). Лучший пример: история с "военным заговором" и "бывшим врангелевским офицером". (За шумом и смехом не слышно оратора). Вы не любите, чтобы здесь об этом говорили. Но факт, что Сталин к этому прибег. Здесь говорили о "нелегальных типографиях", "фракционной работе" и пр. Большевик должен поставить себе вопрос о том, каковы причины всего этого, откуда все это взялось. Неужели все это объясняется неуживчивым характером отдельных людей? (Шум). Нет. Спросите себя, что печаталось в этих "типографиях". Почему, например, завещание Ленина стало нелегальным документом? (Шум)».

Голоса. "Наглец! Негодяй!"

Зиновьев. "Я видел несколько протоколов обысков ГПУ у коммунистов. Среди отобранных «улик» почти всегда фигурирует завещание Ленина. Это достаточно красноречивый факт. (Шум)" ${ }^{\prime 4}$.

Вечером 23 октября 1927 г. Троцкий произнес речь по поводу возможного исключения его и Г. Зиновьева из состава ЦК ВКП(б). Он начал с истории о «врангелевском офицере», военном заговоре и «подпольной типографии»:

«...Бухарин преподносил нам здесь философию термидорианской амальгамы на основе документов Менжинского, не имеющих никакого отношения ни к типографии, ни к оппозиции.

Скрыпник. А вот теперь Щербаков. Вот тебе и на!

Уншлихт. А троцкистская.

Троцкий. ...факты. Фактов нет.

Скрыпник. А Щербаков?

Троцкий. Поэтому весь вопрос вдвинут фуксом в дискуссию об оппозиции. Все документы, оглашенные Менжинским, целиком говорят против проводимой ныне политики, - нужно только эти документы осветить марксистским анализом. Об этом говорил т. Зиновьев. Мне остается поставить вопрос: каким образом и почему руководящая ныне фракция...

Скворцов-Степанов. Фракция?

47 СОРОКИн, КУДРяВЦЕВ, ОДинцОВ, РЕПниКОВ, Объединенный пленум ЦК И ЦКК ВКП(б) 21-23 октября 1927 г., 179. 
Троцкий. ...оказалась вынужденной обманывать партию, выдавая агента ГПУ за врангелевского офицера, и выдергивать осколочки незаконченного следствия для того, чтобы путать партию ложным сообщением об участии оппозиционеров в контрреволюционной организации. Откуда это идет? Куда это ведет? Только этот вопрос имеет политическое значение. Все остальное отступает на второй и десятый план.

Чубарь. Выдвигает на первый план типографию.

Троцкий. В нашей июльской декларации прошлого года мы с полной точностью предсказали все этапы, через которые пройдет разрушение ленинского руководства и временная замена его сталинским ${ }^{48}$.

Смысл стратегии Сталина в борьбе с оппозицией Троцкий выразил кратко:

«...разрушение ленинского руководства партии и временная замена его сталинским» ${ }^{49}$. Он говорил и о тактике: «Основная черта нынешнего курса в том, что он верит во всемогущество насилия - даже по отношению к собственной партии» ${ }^{50}$.

В «Заявлении», написанном Троцким сразу после исключения из состава ЦК ВКП(б), читаем:

«Идейно и политически разбитая сталинская группа прибегла в своей борьбе с оппозицией к неслыханному злоупотреблению политической клеветой. Она грубо нарушает ленинские обычаи и традиции партии, она искажает ленинскую теорию и практику революции, ленинские способы и условия внутрипартийной борьбы она заменяет сталинской "нелояльностью", "грубостью" (Ленин) $)^{51}$.

48 СОРОКИН, КУДРЯВЦЕВ, ОДИНЦОВ, РЕПниКОВ, Объединенный пленУм ЦК И ЦКК ВКП(б) 21-23 октября 1927 г., 197-198.

49 СОРОКИН, КУДРяВЦЕВ, ОДИНЦОВ, РЕПниКОВ, Объединенный пленУм ЦК и ЦКК ВКП(б) 21-23 октября 1927 г., 219.

50 СОРОКИН, КУДРяВЦЕВ, ОДинцОВ, РЕПников, Объединенный пленУм ЦК И ЦКК ВКП(б) 21-23 октября 1927 г., 220.

51 ФЕльштинский, Архив Троцкого (Т.4), 225-226. 
24 октября 1927 г. Троцкий отправил письмо «В Секретариат ЦК», в котором сообщал о недопустимом поведении коммунистов на пленуме, которое к тому же никак не отразилось в стенограмме. В ней не было зафиксировано, что против Троцкого производились хулиганские действия: в него был брошен стакан с трибуны, один из участников пленума «пытался за руку стащить» с трибуны; Ярославский бросил в него «томом контрольных цифр». Троцкий называл эти действия «фашистскими» ${ }^{52}$. Но помимо прочего, речь Троцкого «о постановке в порядок дня особым пунктом вопроса о врангелевском офицере и военном заговоре изъята из стенограммы особым постановлением пленума».

Сталин тоже выступил на октябрьском пленуме. Особый интерес вызывают его рассуждения об оппозиции и «третьей силе»...

Он не забыл, о чем Л. Б. Каменев говорил 6 августа 1927 г. на пленуме ЦК ВКП(б), а говорил он о «третьей силе». Для оппозиции «третья сила»это Н.В. Устрялов, духовный отец сменовеховства, движения, которое стремилось объединить новую экономическую политику в СССР с ценностями буржуазного общества. Сменовеховцы бодро шли на сотрудничество с советской властью, и «левые» во главе со своими лидерами постоянно напоминали, что термидорианская контрреволюция - это перерождение советской власти, это окончательная победа сменовеховцев, которые крайне негативно отзываются о левой оппозиции и бесконечно хвалят режим Сталина.

Вспоминая ленинские изречения, Каменев говорил на пленуме, что для большевистской партии «пропастью» является «вторая партия»в условиях диктатуры пролетариата, ибо возникает «щель», в которую неизбежно проникает «третья сила», враждебная диктатуре пролетариата. Логика его рассуждений: кому выгодно исключение из состава ЦК партии лидеров мировой рабочего движения, Троцкого и Зиновьева? Конечно, третьей силе:

«Поднимет ли это авторитет нашей партии и международного коммунистического движения? Я утверждаю: нет, и вы знаете это! Поднимет исключение тт. Троцкого и Зиновьева и Центрального Комитета обороноспособность СССР? Я говорю: нет! Это ослабит ее. Но я знаю другую силу, которая будет радоваться этому» ${ }^{53}$.

52 ФЕЛьштинский, Архив Троцкого (Т.4), 230-231.

53 А. К. СоРокин, И. И. КудРявцЕВ, А. В. РЕпников (ред.), Объединенный пленум ЦК и ЦКК ВКП(б). 29 июля - 9 августа 1927 г.: Документы и материалы: в 2 кн. (Москва: Полити- 
«Другая сила» - это устряловщина: «я вижу ту силу, которая подталкивает вашу руку к этому шагу. Я не забыл и вы не забыли, что после XIV съезда партии никто иной, как Устрялов, требовал разгрома оппозиции. И он со своей точки зрения был прав. Я знаю - и т. Томский подкрепит меня, что Генсовет в лице своего секретаря Ситрина требовал того, чтобы одернули Троцкого и 3 иновьева» ${ }^{54}$. Но и Каменев был далеко не первый, кто говорил о «третьей силе».

В партии все знали: то, что в устах Ем. Ярославского - всегда на уме Сталина. Ярославский эту тему развивал на утреннем заседании пленума ЦК ВКП(б) 6 августа 1927 г. Он говорил, буквально предвосхищая последующий сценарий борьбы с оппозицией! «Третья сила» - это какие-то молодежные организации (скорее мифические, чем реальные) они поддаются на «клевету оппозиции» и затем выпускают листовки, в которых можно увидеть идеи о реставрации в СССР «конституционной монархии». Ярославский будто тренировался перед решающим сражением, пробуя, как будет воспринимать аудитория всякие странные цитаты из неизвестных никому документов о том, что идеи оппозиции превращаются в идеи контрреволюции. Были найдены и сторонники оппозиции, которые выражали крайне националистические взгляды, а в своих разговорах допускали слова «Бей жидов, спасай Россию» ${ }^{55}$, странные слова, если иметь в виду, что главные лидеры оппозиции были евреями! Сценарий таков:

«Товарищи, должны же вы задуматься над тем, каким образом вас провоцируют контрреволюционеры, почему это происходит, почему к вам имеют возможность примазаться, присоединиться контрреволюционеры?» ${ }^{56}$.

Ярославский не просто заикнулся о контрреволюции, которую вольно или невольно порождает оппозиция, он заговорил о каком-то мифиче-

ческая энциклопедия, 2020. Кн. 2), 158.

54 СОРОКИн, КУДРяВЦЕВ, РЕПниКОВ, Объединенный пленУм ЦК и ЦКК ВКП(б). 29 июля - 9 августа 1927 2., 158.

55 СОРОКИн, КУДРяВЦЕВ, РЕПниКОВ, Объединенный пленум ЦК и ЦКК ВКП(б). 29 июля - 9 августа 1927 2., 113.

56 СОРОКИн, КУДРяВЦЕВ, РЕПниКОВ, Объединенный пленум ЦК и ЦКК ВКП(б). 29 июля - 9 августа 1927 г.,109. 
ском (но допускаемом!) влиянии белогвардейщины! Практически ничего нельзя проверить из того, что он утверждал - но мыслительная деятельность уже шла в этом направлении. Ярославский привел письменный рассказ некоего Таранова, который был привлечен к ответственности за участие в оппозиционной деятельности, а потом чистосердечно объяснился:

«Я до сих пор остаюсь сторонником взглядов оппозиции. Зная, очевидно, об этом, ко мне обращался ряд лиц с предложением начать работу [здесь и далее курсив мой - А.Ю.], т.е. распространять ряд листовок, имевшихся у них в руках. Я попросил дать мне эти листовки для ознакомления. Сперва мне дали один экземпляр листовки на папиросной бумаге, листов пятьдесят, где содержался ответ оппозиции на статью или письмо какого-то товарища, фамилии сейчас не помню, ответ оппозиции не был подписан. Содержание листовки я сейчас не помню, но могу утверждать, что это была не оппозиционная литература, а какая-то контрреволюционная. Я решил проверить это, пошел к одному товарищу-оппозиционеру, образованному человеку, и показал ему. Он взял, стал читать вслух у себя в кабинете, и, прочтя, сказал, что гадость, здесь явно контрреволюционное содержание, надо с этим повести борьбу, и предложил мне передать тем, кто эту литературу дал, чтобы они ее перестали распространять, совсем бы ее уничтожили, так как она ничего общего с оппозицией не имеет. Я, когда с ними встретился дня через два на Люблинской, возвратил листовку и сказал, что это не оппозиционная литература, а белогвардейская, и мы так можем сами играть на пользу белогвардейщины. Они рассердились, стали ругать меня, называя меня утопистом, соломенным философом, говоря, что в литературе есть только большевистское, а не контрреволюционное содержание, что эту литературу им привозят из Москвы, куда ездит специально от них человек. На мой вопрос, кто ее издает, они указали, что Зиновьев, Троцкий, Каменев, а не подписались потому, что теперь этого делать нельзя, вместо подписи ставят «шифр» в виде точек в конце листовки. Я, действительно, видел в конце листовки какие-то точки, запятые, скобки, что это значит - не знаю» ${ }^{57}$.

57 СОРОКИн, КУДРяВЦЕВ, РЕпников, Объединенный пленум ЦК и ЦКК ВКП(б). 29 июля - 9 августа 1927 2.,109. 
Как же строил свои рассуждения на октябрьском пленуме ЦК ВКП(б) генеральный секретарь партии? Какой была его технология «убедительности»? Сознательно или нет, но очевидно, что он пользовался средствами гипнотического воздействия на аудиторию. Не случайно, уже после смерти вождя, многие большевики (А.М. Панкратова, Н.С. Хрущев и др.) вспоминали и даже прямо указывали, что находились «под гипнозом» сталинских выступлений. Они сами удивлялись тому, что верили каждому его слову. С этой точки зрения интересен вопрос - как Сталин строил свое нападение на оппозицию, которая не была глупее или неопытнее, чем он. А между тем, то ли врожденное, то ли благоприобретенное свойство строить свою логику убедительно - с точки зрения массового сознания - заметно отличала Сталина от его умнейших соперников.

Первое, на что следует обратить внимание, это цифровое оформление своих тезисов: почти всегда в докладах и выступлениях Сталина его «пункты». Последовательность рассуждений нисколько не означала, что мысль становится глубже или доказательнее, - нет: она как бы «вбивается» суггестивным путем. Эта стилистика выступлений заметно отличала Сталина от приверженца сугубо рациональной аргументации, каким был Троцкий.

Итак, выступление Сталина на октябрьском пленуме.

Как всегда - «первое». Здесь Сталин обычно находил точку опоры, которую считал нужным утвердить, как абсолютную установку, с которой нельзя не согласиться: от этого зависит убедительность всей аргументации.

Где он ее находил? В собственных рациональных умозаключениях, как это делали Троцкий или Зиновьев? Нет! Он искал установку в мифологическом сознании большинства. То, что не надо доказывать - и так понятно... никто не сомневается! Только тогда, когда он находил этот исходный мифологический субстрат - опору своих последующих рассуждений, только тогда приступал к «маневрированию».

В деле «врангелевского офицера» необходимо было обнаружить устойчивую смысловую «точку опоры», чтобы возразить на утверждение оппозиции о выдумке всего этого дела. Как это сделать? Сталин находит несомненное ядро в объяснении сталинского большинства что-то было, что-то нехорошее, не бывает «дыма без огня». Ради этого был мобилизован и Менжинский с своими рассказами о ходе следствия. Чтобы посеять подозрение, - обратим внимание: подозрение - не есть знание! Это только подозрение. Именно его Сталин в своей речи и превращает в знание, которое нельзя опровергнуть. 
Итак, первый тезис - точка опоры нерефлекторного сознания большинства.

Сообщение т. Менжинского с показаниями арестованных не оставляет никакого сомнения в том, что одна часть «работников» нелегальной антипартийной типографии троцкистов связана, безусловно связана, с контрреволюционными элементами из белогвардейцев [курсив мой - А.Ю.]. Пусть оппозиция попробует опровергнуть эти факты и документы»58.

Это первый и самый важный суггестивный момент - безусловное «безусловно» с точки зрения подозрения, но не знания.

Пункт второй. Он продумывался заранее. Это была интрига, точный расчет.

«Мы только что получили последний номер этого грязного листка ренегата Маслова [немецкого издания «Знамя коммунизма» - А.Ю.], занятого тем, чтобы клеветать на СССР и выдавать государственные тайны СССР буржуазии. В этом органе печати опубликованы, в перевранном виде, показания белогвардейцев и их союзников из нелегальной антипартийной типографии во всеобще сведение.

Голоса. Здорово!

Сталин. Откуда мог получить Маслов эти сведения? Сведения эти являются секретными, так как не все еще разысканы и арестованы из того кружка белогвардейцев, который замешан в деле организации заговора по типу заговора Пилсудского. С этими показаниями познакомились в ЦКК Троцкий, Зиновьев, Смилга и другие оппозиционеры. Им было воспрещено пока что снять копию с этих показаний. Но они, видимо, все-таки сняли копию и постарались переслать Маслову. Но что значит передать эти сведения Маслову для публикации?»

Обратим внимание на то, что отправить копию показаний арестованных могли не только оппозиционеры, но и по тайному распоряжению Сталина. Это одна из возможных интриг. Конечно, это мог сделать кто-то из оппозиции: что тоже не исключает провокации. Опять же это не факты, это подозрения! Как ими воспользовался Сталин? Он сде-

58 СОРОКИн, КУДРяВЦЕВ, ОДинцОВ, РЕПников, Объединенный пленум ЦК и ЦКК ВКП(б) 21-23 октября 1927 г., 212. 
лал вывод в своей речи, который полностью повторил тезис первый о какой-то (неясно какой!) несомненной связи оппозиции с контрреволюцией. И теперь «убедительность» установки превращалась (мифически) в убедительность, подтвержденную «фактом», а именно: они отправили сообщение Маслову и таким образом (!) предупредили скрывающихся белогвардейцев о возможных арестах.

Но что значит передать эти сведения Маслову для публикации? Это значит дать предостережение тем белогвардейцам, которые еще не разысканы и не арестованы, дать предостережение о том, что большевики намерены их арестовать. Хорошо ли это, допустимо ли это для коммунистов? Ясно, что недопустимо. Статья в органе Маслова имеет пикантный заголовок «Сталин раскалывает ВКП. Белогвардейский заговор. Письмо из СССР».

Голоса. «Мерзавцы» ${ }^{59}$.

Чтобы обезопасить себя от спора о причастности оппозиции к контрреволюции - хотя он только что сказал, что она причастна - Сталин утверждает, что нет никаких оснований говорить об участии оппозиции в военном заговоре.

Такая сталинская «диалектика»!

Сталин. «Что вытекает из этих показаний, из сообщения т. Менжинского? Обвиняли ли мы когда-либо, или обвиняем ли мы теперь оппозицию в устройстве военного заговора? Конечно, нет. Обвиняли ли мы когда-либо, или обвиняем ли мы теперь оппозицию в участии в этом заговоре? Конечно, нет.»

Если человек соглашается с этими утверждениями Сталина, а как тут не согласиться, если все получают то, что хотят: обвинители - нужное обвинение, а оппозиция - необходимое оправдание, то приходится верить каждому слову Сталина, ибо граница смысла, различающая правду от неправды уже стерта гипнотической «диалектикой».

Ни Троцкий, ни Зиновьев так не умели!

Сталин усиливал «защиту» оппозиции от собственных же обвинений:

Обвиняли ли мы когда-либо, или обвиняем ли мы теперь оппозицию в участии в это заговоре? Конечно, нет.

59 СОРОКИн, КУДРЯВЦЕВ, ОДинцОВ, РЕПниКОВ, Объединенный пленУм ЦК И ЦКК ВКП(б) 21-23 октября 1927 г., 212-213. 
Муралов. «На прошлом Пленуме обвиняли.

Сталин. Неверно, т. Муралов. У нас имеются два извещения ЦК и ЦКК о нелегальной антипартийной типографии и о беспартийных интеллигентах, связанных с этой типографией. Вы не найдете в этих документах ни одной фразы, ни одного слова, говорящих о том, что мы обвиняем оппозицию в причастности к военному заговору. ЦК и ЦКК утверждают в этих документах лишь то, что оппозиция, организуя нелегальную типографию, связалась с буржуазными интеллигентами, а часть этих интеллигентов, в свою очередь, оказалась в связях с белогвардейцами, замышляющими о военном заговоре.

муралов. А в стенограмме записано?

Голос. В какой стенограмме?

Сталин. Я бы просил т. Муралова указать соответствующее место в документах, изданных Политбюро ЦК и Президиумом цКК в связи с этим вопросом. Тов. Муралов не укажет, ибо таких мест не существует в природе»60.

Но в чем тогда виновата оппозиция? Этот вопрос нельзя оставить без ответа. Вновь возникает сталинская неопределенность смысла, которая грозит закрутить новый виток «диалектики».

И опять «пункты».

Во-первых: оппозиция организовала антипартийную нелегальную типографию. Этот пункт бесспорен для большинства на Пленуме цК и ЦКК.

Во-вторых:

«...для организации этой типографии оппозиция вошла в блок с буржуазными интеллигентами, часть которых оказалась в прямой связи с контрреволюционными заговорщиками».

Вина оппозиции не в том, что она участвовала в заговоре, а в том, что она имела какую-то«связь» с теми, кто имел связь с противниками советской власти. Здесь мы видим смешение реальности с воображаемым. Вина рассматривается не в модусе рациональном (было - не было), а в модусе паранойи (ничего не было - но было).

60 СОРОКИН, КУДРяВЦЕВ, ОДинцОВ, РЕПниКОВ, Объединенный пленум ЦК и ЦКК ВКП(б) 21-23 октября 1927 г., 213. 
В-третьих: вина оппозиции заключается в том, что вина эта - «помимо воли». Здесь смешение реальности с воображаемым достигает своего максимума:

«...привлекая к себе буржуазных интеллигентов и конспирируя с ними против партии [! - А.Ю.] оппозиция оказалась, помимо своей воли, помимо своего желания [курсив мой - А.Ю], в окружении так называемой третьей силы» ${ }^{61}$.

Сталин делает выводы, базирующиеся не на доказательствах рационального плана, а на подозрениях, страхах, стереотипах мышления. «Цепочка» умозаключений такая:

«Оппозиция хотела иметь антипартийную нелегальную типографию; она обратилась для этого к помощи буржуазных интеллигентов; а часть из этих последних оказалась в связях с прямыми контрреволюционерами, - вот такая цепочка получилась, товарищи. Оппозицию облепили, помимо ее воли, помимо ее желания [курсив мой - А.Ю.], антисоветские элементы, старающиеся использовать в своих целях раскольническую работу оппозиции» ${ }^{62}$.

Сталин одновременно обвинял и оправдывал. Оппозиция виновата, но «помимо желания», «помимо воли»! Исчезал ясный и определенный смысл; человек оказывался в «королевстве кривых зеркал», и без опыта рефлексии невольно попадал под магнетизм «диалектических» упражнений вождя партии.

Объективизм превращался в религию: надо было крепко верить в независимую от человека сущность процесса, чтобы допускать вину «объективную», а не личную, вину - саму по себе, по ходу своеобразной пьесы, в которой ты невольно исполняешь роль преступника, не будучи им по факту. В свое время Н.А. Бердяев определил религию объективизма в духе Людвига Фейербаха как порочную марксистскую метафизику, в которой допускалась мысль, что человек никогда не сможет стать полноценным, равным своему коллективистскому идеалу, ибо он всегда - только «дробь» человечества (как выражался А.А.

61 СОРОКИн, КУДРявЦЕВ, ОДинцОВ, РЕПниКОВ, Объединенный пленУм ЦК И ЦКК ВКП(б) 21-23 октября 1927 г., 213.

62 СОРОКИН, КУДРяВЦЕВ, ОДИНЦОВ, РЕПниКОВ, Объединенный пленУм ЦК и ЦКК ВКП(б) 21-23 октября 1927 г., 213. 
Богданов, яркий продолжатель учения Фейербаха): такая малая часть, что ею всегда можно пожертвовать ради целого - ради человечества («большинства»). Подобная установка не была личной - это установка, присущая марксистско-позитивистскому массовому сознанию...

В «Крокодиле» воспроизводилась сталинская технология внушения, подхваченная и усвоенная «на ходу». В номере 37 за 1927 г. - это первая неделя октября - была опубликована статья Н. К. Иванова-Грамена, редактора журнала, под названием «Ничего такого». Изображался человек, который не понимает, по какой причине его исключили из партии что «такого» он сделал? Задавал ему вопросы человек как бы от лица «большинства».

«- ... Неужели за один шаг исключили?

- Ну, за два шага. На 38-ю версту, что ли, я ездил? Всего и ходьбы-то от моей квартиры до той два шага было...

- До какой той?

- Обыкновенно, какие бывают. Ничего особенного: квартира, как квартира.

- А в квартире-то что?

- Да ничего. Так, печатали мы там кое-какие вещицы...

- Постой... Как так - печатали? Значит, там типография была?

- Ну уж, типография, тоже!.. Поглядел бы ты, какие в Америке или в Англии типографии бывают! А у нас - так, кустарненькая... Есть о чем разговаривать, подумаешь!..

- Подожди, я не совсем понимаю... Это легальная типография?

- Если б от нас зависело, - была бы легальная. Какая разница? Вообще, что тут такого, скажи на милость?.. Ну печатали мы...

- Постой... Кто это вы?

- Ну, вообще... Которые в оппозиции - ну, и всякие там...

- акие всякие? Белогвардейцы, что ли?..

- Был, кажется, и белогвардеец один... На беспартийном - на нем не написано, кто он такой!

- Ну-ну!.. Как же тебя угораздило в такую компанию затесаться?

- Я не затесался. Мы сами их пригласили...

- Для чего?.

- А печатать и распространять. Нам одним не управиться!..

- Что распространять?

- Да так, против нынешнего руководства и вообще... Платформы всякие... 
- Антипартийные?.

- Это по-твоему - антипартийные. А если бы мы партией были, то и платформы были бы партийные. Чего ты к словам придираешься? Вообще, все это несущественно, и не о том я с тобой разговариваю...

- Как, то есть, не о том? А о чем же?

- А вот о том, что исключили меня... За что, спрашивается? Неизвестно. Так, здорово живешь. Ничего такого я не делал, и вообще...» ${ }^{63}$

В номере 39 за 1927 г., вышедшем в свет на третьей неделе октября, был опубликован небольшой рисунок, иллюстрирующий то, как молодой человек гордится своим «подпольным стажем» - и сама типография названа «подпольной».

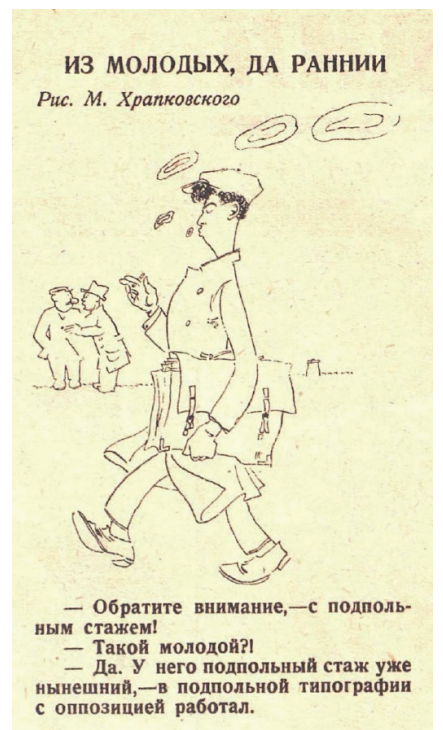

На той же странице был опубликован очерк упомянутого Грамена «Катехизис парт-оппозиционера», в котором вновь прозвучал мотив о невозможности никакой оппозиции. Это тоже следует отнести к сталинской суггестии, ибо в аргументах оппозиции видно большое недоумение перед сталинской манерой прекращать всякие дискуссии под предлогом, что они антипартийные, - не было такого раньше.

63 Н. К. ИваНОВ-ГРАМЕН, «НичеГо таКоГо», КроКодиЛ, по. 37 (1927): 2. 
«Bonpoc. Можно ли парт-оппозиционеру заниматься строительством социализма?

Oтвет. Сие возбраняется не в силу принципиальных причин, а по причине отсутствия времени.

Bопрос. Куда же оно девается?

Oтвет. Оное не девается, но его надлежит употреблять на дискуссию и на составление платформ.

Bonpoc. На что еще потребно время, расточительно употребляемое другими на строительство социализма?

Oтвет. На размножение и распространение оных платформ...» ${ }^{64}$

В журнале «Крокодил» был придуман образ Савелия Октябрева беспартийного, который своим мыслями и действиями разоблачал самого себя, в том числе и тем, что примкнул к оппозиции. В номере 40 за 1927 г., вышедшем на последней неделе октября, был опубликован сатирический очерк «Уклон Савелия Октябрева», в котором было заявлено:

«Редакция "Крокодила" только что пережила потрясающую неожиданность: гр. Савелий Октябрев (беспартийный) впал в парт-оппозицию» ${ }^{65}$.

Здесь обыгрывалось то, что в деле о «типографии» считалось - с точки зрения партийного руководства - особо недопустимым соучастие беспартийных интеллигентов («буржуазных» по своей природе). Лживая информационная смесь, приготовленная Сталиным для дискредитации оппозиции, подавалась в журнале «Крокодил» дозировано, но точно попадая в эпицентр подозрений со стороны «большинства», - оппозиция не только с беспартийными дружит, но и с «не совсем» советскими - тоже:

«Савелий Октябрев, не дав нам закончить вопрос, ответил со свойственной ему обстоятельностью:

- До сведения моего доведено газетами, что в некоторых фракционных собраниях парт-оппозиции принимали участие беспартийные и даже, до известной степени, не совсем советские элементы....»66

64 Н. К. ИвАНОВ-ГРАМЕН, «Катехизис революционера», Крокодил, по. 37 (1927): 2.

65 Савелий Октябрев, «Уклон Савелия Октябрева», Крокодил, по. 40 (1927): 2.

66 Савелий Октябрев, «Уклон Савелия Октябрева»: 2. 
Тема участия беспартийных в «типографском деле» оказалась живучей и важной. В номере 41 за 1927 г, вышедшем на первой неделе ноября, Грамен опубликовал еще один очерк под названием «Записки с пути сошедшего». В нем сообщалось, что цик СССР выпустил манифест о переходе на семичасовой рабочий день:

«Я не одобряю. По-моему, выпускать должна парт-оппозиция - и не манифесты, а платформы. Делать их нужно в подпольной типографии [курсив мой - А.Ю.], по ночам, а затем, днем с фонарем, искать сочувствующих. К сожалению, сейчас все делается не так, как нужно. Строится, например, социализм в одной стране, а согласны ли на это Урбанс или Маслов - даже не спрашивают. Беспартийный интеллигент Щербаков тоже, может быть, не согласен, но почему-то обходятся и без него. Где же тут, спрашивается, внутрипартийная демократия?!»67.

Последующие события празднования Октябрьской революции привели главных фигурантов оппозиции к исключению из партии. Этот вопрос был решен уже в октябре, на пленуме, ждали только начала XV съезда партии (он открылся 2 декабря 1927 г.), чтобы окончательно расправиться с неугодными лидерами. Конфликтное празднование 7 ноября 1927 г. с параллельной манифестацией оппозиции, драками, провокациями ускорило процесс. В №44 журнала «Крокодил» появляется карикатура с названием «Подпольная типография», - перед открытием $\mathrm{XV}$ съезда ВКП(б), - в которой мы видим уже изменившийся взгляд на «нелегальную типографию» (так ее называл Сталин на октябрьском пленуме) - она стала «подпольной типографией», т.е. антисоветской, в ней непосредственно работают лидеры оппозиции, они непосредственно (своими руками) печатают антипартийные материалы, они совмещаются с подпольем без всяких прежних оговорок.

Сталину не с кем больше спорить о том, насколько оправдано насилие против членов большевистской партии. Ему не перед кем увиливать от неприятных вопросов. На смену эпохи противоборства групп и фракций приходит эпоха, в которой стремительно расширяется сталинское понимание «правды» как смешение того, что было и того, чего не было и быть не могло. Сталинская паранойя, обращенная в массы, постепенно становится доминирующей - о чем и свидетельствует ка-

67 Н. К. ИВАНОВ-ГРАМЕН, «ЗаПИСКИ СошеДШеГо С ПУти», КроКодил, по. 41 (1927): 2. 
рикатура в 44 номере журнала «Крокодил» за 1927 г., едва ли не первая весточка нарождающегося сталинизма.

\section{References}

IU. G. FEL'SHTINSKII (red.), Arkhiv Trotskogo. Kommunisticheskaia oppozitsiia v SSSR. 1923 - 1927 [Trotsky Archives. Communist opposition in the USSR. 1923 - 1927] (Moskva: «Terra», 1990. T. 4).

M. S. FISHELEV, Ot khar'kovskoi golubiatni do angarskoi ssylki [From the Kharkov dovecote to the Angarsk exile] (Moskva: Izdatel'stvo Politkatorzhan, 1931). Krokodil [Crocodile], 1927.

A. K. SOROKIN, I. I. KUDRIAVTSEV, M. I. OdINTSOV, A.V. REPNIKov (red.), Ob"edinennyi plenum CK i CKK VKP(b) 21-23 oktiabria 1927 g.: Dokumenty i materialy [Joint Plenum of the Central Committee and the Central Control Commission of the All-Union Communist Party (b) October 21-23, 1927: Documents and materials] (Moskva: Politicheskaia entsiklopediia, 2018).

A. K. SOROKIN, I. I. KUdRIAVTSEV, A. V. RepNikov (red.), Ob"edinennyi plenum CK i CKK VKP(b). 29 iiulia - avgusta 1927 g.: Dokumenty i materialy: v 2 kn. [Joint Plenum of the Central Committee and Central Control Commission of the All-Union Communist Party (Bolsheviks). July 29 - August 9, 1927: Documents and materials: in 2 books]. (Moskva: Politicheskaia entsiklopediia, 2020. Kn. 2). 